\title{
Profitability and the Distance to Default: Evidence from Vietnam Securities Market
}

\author{
Van Thuy Thi VU', Nhung Hong DO ${ }^{2}$, Hung Ngoc DANG ${ }^{3}$, Tram Ngoc NGUYEN ${ }^{4}$
}

Received: June 07, 2019 Revised: September 16, 2019 Accepted: September 24, 2019

\begin{abstract}
The paper examines the influence of profitability on distance to default (DD) in Vietnam securities market. The investigated sampl e consists of 211 companies listed on HOSE during 18 years from 2010 to 2017 . We apply KMV model to calculate distance to d efault and use both macroeconomics factors and firm specific factors as independent variables. Using General Least Squared (GL S) method, we find evidence to confirm the positive relationship between profitability and distance to default. This result showed t hat, although profitability did not directly reflect the cash flow generated, a good profitable enterprise would be an important facto $\mathrm{r}$ to help facilitate and generate cash flow and at the same time debt was guaranteed when it was due. Besides, the test results rev ealed that the financial structure and sales on assets have the inverse effect on the distance to default at the significance level o f 5\%. The results also revealed that a group of macro factors had an influence on the distance to default of businesses, including spre ad, GDP and trade balance (via exchange rates). Gross domestic income had certain impacts on the distance to default of businesse s. This was also a basic indicator measuring the national economic cycle.
\end{abstract}

Keywords : Distance to Default, General Least Squared, KMV Model, Profitability, Vietnam Securities Market

JEL Classification Code : G00, G01, G30, G32, G33

\section{Introduction}

Over the past few years, the world economy in general and Vietnam in particular have undergone many changes after the economic crisis. The decline and instability among the components of the economy have had a great impact on the operation of enterprises. In fact, the number of enterprises which operate ineffectively, go bankrupt or are dissolved is

1 First Author and Corresponding Author, Lecturer, School of $\mathrm{Ba}$ nking and Finance, National Economics University, Vietnam. [Postal Address: Room 909 A1 Building, School of Banking and Finance, National Economics University, 207 Giai Phong Street, Hanoi, 100000, Vietnam] Email: thuyvan1507@gmail.com

2 Lecturer, School of Banking and Finance, National Economics University, Vietnam. Email: nhungdh@gmail.com

3. Lecturer, Hanoi University of Industry, Vietnam. Email: hungdangngockt@yahoo.com

4. Lecturer, School of Banking and Finance, National Economics University, Vietnam. Email: tramnn@neu.edu.vn

(c) Copyright: Korean Distribution Science Association (KODISA)

This is an Open Access article distributed under the terms of the Creative Commons Attribution Non-Commercial License (http://Creativecommons.org/licenses/by-nc/4.0/) which permits unrestricted noncommercial use, distribution, and reproduction in any medium, provided the original work is properly cited. increasing. To remedy the negative changes in production and business activities and overcome the post-crisis volatile period, one of the current strategic orientations of Vietnamese enterprises is to minimize risks exposed to the business. Risks in the process of development are inevitable, especially in the context of integration, which can cause production and business activities of enterprises to be seriously affected, even leading to bankruptcy. If the business can build itself a risk management system, the consequences can be maximally limited.

Although there have been certain progresses recently made in the risk management of Vietnamese enterprises, it only increases the awareness level of risk management role or "orientation to complete the policy system on risk management". In particular, the investment in risk management functions which is shown through the annual operating budget for these departments is quite modest. According to the results of the survey, the majority of new businesses set aside budgets of less than $1 \%$ of the total operating costs of the enterprises for the functional departments to manage risks, of which $25 \%$ responded that they did not have the operating budget for risk management 
functions. Therefore, risk management of enterprises will be an urgent issue that needs to be studied in the current period.

In order for risk management to achieve good results, risk evaluatation and estimation are of great importance. In particular, the risk of insolvency is a research matter that should be paid attention to, especially after the financial crisis in 2008. In fact, the situation of debts and bad debts in enterprises that have been arising proves to be hard to control. Currently, some businesses listed on the stock market are utilizing high financial leverage. Many businesses borrowed by issuing bonds and accepting high interest rates to get away with credit risk control regulations when borrowing to implement projects. This source of funding can be invested in high-value real estate or agricultural projects but it is still subject to high risks of cash flow. In order to avoid "default," these businesses must constantly extend debt, utilize the new loans to pay off the old ones, or sell off assets to pay the debts. However, in case, for some reason, "cash flow" from the bank is tightened, it is likely that these enterprises will fall into the "default" status. In that case, however great the asset is, enterprises could still face the risk of bankruptcy. A business using debt always has to face financial risks. An enterprise with a high debt ratio sometimes falls into a situation of excessive prudence in its investment decisions, easily ignoring good opportunities of investment or increasing profitability, which is against the objectives of business value maximization. Negative influences from the crisis in 2008 were still persistent and the number of insolvent and bankrupt businesses was increasing rapidly in recent times. Therefore, it is necessary to assess the influencing factors, especially the profitability of the business on the risk of default.

In Vietnam, the fact has shown that the use of analytical and measuring tools towards risk of default is quite common for banks and insurance companies. However, based on the research overview, Distance to Default (DD) proved to be a popular method applied in the world with such advantages as:

$\checkmark \quad$ allowing updating the possibilities of insolvency of the business over time and ensuring objectivity due to continuous stock prices and reflecting corporate value

$\checkmark \quad$ evaluation may be applied to all public companies.

$\checkmark \quad$ ability to evaluate the company of this model is very high.

$\checkmark \quad$ having a more solid basis than other models

$\checkmark \quad$ capabability of predicting bankruptcy and ranking very well in all corporate situations.

Meanwhile, this method has not been used and exploited in risk management of Vietnamese businesses. Therefore, the authors would like to propose to apply DD tools in measuring the risk of default of businesses, while focusing on assessing the impact of profitability on the distance to default.

\section{Research Overview}

\subsection{Distance to Default}

The Distance to Default (DD) concept was derived from the model developed by Kealhofer, McQuown and Vasicek based on Merton's model (1974). Merton's (1974) model proposed a method to measure the risk of default through a measure called a distance to default (DD). The basic assumption of the model of DD measurement is that a business is considered insolvent when the market value of the total assets of that business falls below its default point (Merton, 1974). In the model of measuring DD, the probability of default depends on the value of the market value of total assets, the book value of the due debts and the volatility of the market value of total assets of the business. The model calculates the probability of default through a composite parameter, which is DD, i.e. the distance between the expectation of the market value of total assets of the business to the point of default. Merton model (1974) had become the basis for a variety of later model development researches of measuring the distance to defaults.

Based on Merton's (1974) model, Kealhofer, McQuown and Vasicek developed a formula for calculating the distance to default, rejected the hypothesis of a standard distribution of distance to default and gave out the method of calculating the expected default frequency (EDF). In 1989, Kealhofer, McQuown and Vasicek founded KMV company, named after three people. Since then, the KMV model has been widely used to forecast the frequency of default of enterprises in practice as well as being a research topic for many scholars. The outstanding feature of KMV model was that the model allows determining the frequency of default at any time, not only at the time of debt maturity. In general, the model consists of three main steps to determine a firm's default probability. First, the model determines the value of the market value of total assets of the business and its volatility through stock prices, stock price volatility and the value of the debt limit. Second, the distance to default value is calculated based on the market value and the volatility of the asset. Third, based on actual data, the model builds up the relationship between distance to default and expected default frequency (EDF). This relationship allows forecasting the default frequency of the business based on the defined distance to default.

In order to test whether the use of KMV model is effective or not, many researchers have compared KMV model with others of credit risk measurement and proposed to develop further KMV model. Jessen and Lando (2015) have found evidences proving corporate default risk ratings based on measuring the distance to default is more effective than the credit rating model based on the Leland model (2002), Arora, Bohn and Zhu (2005) conducted a comparison of the effectiveness of default risk prediction between the model of measuring the distance to default and those based on the accounting variables such as the $\mathrm{Z}$ model of Altman (1968), Ohlson's O score, reduce form model, and came to a conclusion that the Merton model of distance to default measurement could predict default risk more effectively than those based on ordinary accounting variables. Le (2010) clearly pointed out advantages and 
disadvantages of KMV model. Le and Le (2012) combined CVaR with Merton model by building up the conditional distance to default (CDD) to calculate the conditional probability of default (CPD).

\subsection{Factors That Affect the Distance to Default}

Many studies pointed out macroeconomic factors influencing the distance to default (Pesaran \& Schuermann, 2003; Laurin \& Martynenko, 2009; Qu, 2008). According to Laurin and Martynenko (2009), macroeconomic factors could explain $75 \%$ of the changes in distance to default of large enterprises (this value was $68 \%$ for small and medium enterprises). In their study, Laurin and Martynenko (2009) indicated the lag 1 of the industrial production index and the lag 1 of the SEK/EUR exchange rate had directly proportional effect on the distance to default (inversely proportional for probability of default); Short-term and lag 1 of short-term interest rates have the inversely proportional effect on distance to default. Qu (2008) found the evidence showingthat CPI, basic interest rate difference, industrial production value and unemployment rate have an influence on the distance to default of businesses in Sweden.

There have not been many studies on micro factors influencing the distance to default of the business which only focused on the banking sector. When studying the banking industry, Blundell-Wignall and Roulet (2013) showed that house prices, relative size of banks, leverage, market value of derivative securities, trading assets, and loan from banks and foreign revenues affected the distance to default of banks. Also a study about banks, Lam and Phan (2009) argued that the maximum loan rate on guaranteed assets, the number of times borrowers used assets which were formed from loans as the guaranteed assets to continue borrowing and the purpose of using loans had an influence on the distance to default. However, this study only dealt with the arguments and there hasn't been any specific evidence.

In general, no researcher has provided a complete work on the factors influencing the distance to default of enterprises, especially for studies conducted in Vietnam. Most of the domestic research papers which are related to the model of measuring distance to default are model applications that endeavors to explain a certain phenomenon on the stock market or in the banking system. Although the study initially argued the relationship between the probability of default and other variables, the results have not been empirically proved and the scope of application is only limited to the banking operation.

\subsection{The Relationship between Profitability and Distance to Default}

Studies on the relationship between profitability and distance to default of enterprises have not been paid proper attention to. Researchers have not directly mentioned the distance to default as a measure of the risk of default, but only dealt with the probability of default or financial difficulties of the business. Specifically, Pranowo, Achsani, Manurung, and Nuryartono (2010) asserted that profitability is one of the factors that have a great impact when predicting financial difficulties of enterprises. Yadiati (2017) found similar results when using net profit margins as a measure of profitability. Ufo (2015) found evidences showing that when profitability increases, the business probability of default also goes up. However, Yadiati (2017), when analyzing the impact of financial profitability on enterprises listed on the Indonesian stock market, didn't find out any evidence of a meaningful relationship between these two criteria. In his study, Yadiati (2017) measured financial difficulties via the $\mathrm{Z}$ coefficient of Altman (1968). This is a simple study, which did not use various measures to determine the level of corporate financial difficulties.

In summary, in Vietnam, there has been no research on the relationship between profitability and distance to default. Researches in the world on this relationship are limited, with the ones in existence only dealing with other measures of risk of default or approaching towards macro factors without paying attention to micro ones of the business. Domestic researchers have only focused on measuring the distance to default, especially at commercial banks, or conducted qualitative analysis of KMV model. Therefore, it is necessary to discover the evidence for this relationship in Vietnam.

\section{Research Model}

\subsection{Research Data}

The research sample included 211 enterprises listed on Ho Chi Minh City Stock Exchange in the period of 2010 2017, which were selected on the following basis: Enterprises are required to have sufficient data of research variables: Income statement, balance sheet, cash flow statement, stock price record data. Data is provided by Stoxplus Corporation, which has changed its name to FiinGroup Corporation recently.

\subsection{Research Variables}

\subsubsection{Dependent Variables}

According to previous studies on default risk, the probability of default (PD) which was calculated from Merton model is an index of assessing default risk of enterprises. However, the probability of default (PD) is not statistically appropriate to be used as the dependent variable in the regression model when considering the impact of economic factors on the default risk. Since the actual value of the default probability is usually close to zero and is only in the range of 0 to 1 , to avoid these limitations, the variable of distance to default is used as the dependent variable in regression models. Following research of Bharath and 
Shumway (2004), the variable of distance to default is closely related to the default probability which is determined by the debt gap according to the formula:

$$
P D=\Phi(-\mathrm{DD})
$$

The greater the distance to default is, the lower the default probability of the enterprise will be, the more likely it is for an enterprise to fulfill its financial obligations. On the contrary, the smaller the distance to default is, the higher the default probability will be. The chosen dependent variable is the distance to default of the business.

$$
\mathrm{DD}_{i t}=\left(\frac{\ln \mathrm{V}_{i t}-\ln \mathrm{D}_{i t}}{\sigma_{V i}}\right)
$$

In which:

$D D_{i t}$ : Distance to default of the business $i$ at the time t.

$\ln \left(V_{0 i}\right)$ : Logarit base e of market value of total asset of the business $\mathrm{i}$.

$\sigma_{0 t}$ : the voltality of market value of total assets for the business $\mathrm{i}$

$D_{i t}$ : Default point of the business $i$ at the time t.

In order to determine DD in the formula, three values required to be found out are $\mathrm{V}_{0}, \sigma_{V}$ and $\mathrm{D}$.

Two methods were applied to determine the values of $\mathrm{V}_{0}$ and $\sigma_{V}$ :

Determination of $V_{0}$ and $\sigma_{V}$ through a nonlinear equation system

To determine these two values, a nonlinear equation system can be used:

The first equation is according to the formula BlackScholes:

$$
E=V . \Phi\left(d_{1}\right)-e^{-r \cdot T} \cdot \mathrm{D} . \Phi\left(d_{2}\right)
$$

In which:

E: equity value

$\mathrm{V}$ : market value of asset

r: risk-free interest rate

D: default point

$$
\begin{aligned}
& d_{1}=\frac{\ln \left(\frac{V_{0}}{D}\right)+\left(r+\frac{1}{2} \sigma_{V}\right)}{\sigma_{V}} \\
& d_{2}=d_{1}-\sigma_{V}
\end{aligned}
$$

The second equation is according to Crouhy, Mark and Galai (2001) stated in Risk Management textbook.

$$
E_{0}=\frac{\sigma_{V}}{\sigma_{E}} \Phi\left(d_{1}\right) \cdot V_{0}
$$

However, the fact has shown that the results obtained from the assumption of nonlinear equations are not accurate in comparison with reality. Therefore, KMV model has proposed another method which is based on computer technology and empirical value to determine $\mathrm{V}_{0}$ and $\sigma_{V}$.

\section{Determination of $V_{0}$ and $\sigma_{V}$}

KMV model provided an iterative process to determine these two values from the market value of the enterprise's equity based on the formula of determining the equity value in Merton model (Black - Scholes formula).

$$
E=V . \Phi\left(d_{1}\right)-e^{-r . T} \cdot \mathrm{D} . \Phi\left(d_{2}\right)
$$

In which:

E: equity value

$\mathrm{V}$ : market value of asset

r: risk-free interest rate

D: default point

$$
\begin{aligned}
& d_{1}=\frac{\ln \left(\frac{V_{0}}{D}\right)+\left(r+\frac{1}{2} \sigma_{V}\right)}{\sigma_{V}} \\
& d_{2}=d_{1}-\sigma_{V}
\end{aligned}
$$

An iterative process is conducted using the formula above:

Supposedly, we have a daily series of data $\mathrm{E}_{\mathrm{t}}$.

$\checkmark \quad$ Step 1: Run the value $\sigma_{V}=\sigma_{E}$

$\checkmark \quad$ Step 2: Calculate the series of data $V_{t}$ from the series $S_{t}$ in accordance with the formula Black_Scholes and existing value $\sigma_{V}$.

Step 3: Recalculate the value $\sigma_{V}$ from the newly generated series $\mathrm{V}_{\mathrm{t}}$.

$\checkmark \quad$ Step 4: Repeat step 2 .

$\checkmark \quad$ This process was repeated many times until the values $\sigma_{V}$ of two consecutive iterations were close enough. From then, the values of $\mathrm{V}_{0}$ and $\sigma_{V}$ were determined.

\subsubsection{Independent Variables}

Micro variables

On the basis of external studies which have performed an analysis of influencing factor on the distance to default and other default risk researches, the research used independent variable groups which reflects the profitability of the business including:

Return on Assets (ROA)

This ratio reflects the efficiency of using assets to serve the production and business activities of an enterprise. The change of ROA have an impact on investors' expectations towards an enterprise, thus affecting the total asset market value of that business. The distance to default is determined based on the market value of the total assets of the enterprise, so it is subject to the influence of ROA (Pranowo et al., 2010). 


\section{Return on Equity (ROE)}

$\mathrm{ROE}$ is the ratio of net profit in the period over the total average equity of the same period. This ratio is often analyzed by investors to compare shares in the same industry in the market before being referred to when making investment decisions. Therefore ROE often has an impact on the stock price of the enterprise or the total asset market value of that enterprise. The distance to default is determined based on the market value of the business' total assets and therefore subject to the impact of ROE (Pranowo et al., 2010).

Sales on Assets (SOA)

This is one of the criteria which were used to evaluate the efficiency of using corporate assets. The more difficulties the business has to face in using assets, the closer it is to the state of default and the shorter the distance to default will be (Yadiati, 2017)

Financial leverage

Financial leverage is measured by the ratio of liabilities on equity. This is an indicator that reflects the default scale in comparision with the equity of the enterprise, showing the capacity of the enterprise to fulfill its financial obligations in the long term. When the ratio of financial leverage changes, the point of default and the market value of the total assets of the business will vary, leading to the variation of the distance to default. (Blundell-Wignall \& Roulet, 2013).

Business scale

Normally, the larger the enterprise, the more stable it is and the more likely it is to overcome the economic upheaval than the small ones. Laurin and Martynenko (2009) pointed out that the distance to default is influenced by the firm size.

\section{Macro variables}

Spread

The interest rate represented the cost which the borrowers had to pay the creditor to have the right to use the loan. Therefore, fluctuations in interest rates have an impact on the distance to default of enterprises. The research that was conducted by Laurin and Martynenko (2009) showed that interest rates and lag 1 of interest rates have an impact on the distance to default of enterprises.

Gross Domestic Product (GDP)
GDP is closely related to investment and credit activities. The relationship between GDP and corporate distance to default was stated in the study conducted by Figlewski, Frydman, and Liang (2012).

\section{Exchange rate of USD/VND (Exrate)}

The exchange rate of USD / VND is the price of the USD against the VND price. Enterprises in economic sectors with many international trade activities such as fisheries were affected by the USD / VND exchange rate. The research carried out by Laurin and Martynenko (2009) pointed out the impact of exchange rates on the distance to default.

\subsection{Research Model}

Based on an overview of the study and the analysis of the relationship among variables in the model, the regression model is proposed in the study to test hypotheses of the following form:

The model showed the influencing factors on the distance to default of enterprises in Vietnam stock market.

$$
\begin{aligned}
\mathrm{DD}_{\mathrm{it}}= & \beta_{0}+\beta_{1} \mathrm{ROE}_{\mathrm{it}}+\beta_{2} \mathrm{SIZE}_{\text {it }}+\beta_{3} \mathrm{SOA}_{\text {it }}+\beta_{4} \mathrm{DOE}_{\text {it }}+ \\
& \beta_{5} \text { Spread }_{\mathrm{it}}+\beta_{6} \mathrm{GDP}_{\mathrm{it}}+\beta_{7} \text { Exrate }_{\mathrm{it}}+\varepsilon_{\mathrm{it}} \\
\mathrm{DD}_{\mathrm{it}}= & \beta_{0}+\beta_{1} \mathrm{ROA}_{\mathrm{it}}+\beta_{2} \mathrm{SIZE}_{\mathrm{it}}+\beta_{3} \mathrm{SOA}_{\text {it }}+\beta_{4} \mathrm{DOE}_{\text {it }}+ \\
& \beta_{5} \text { Spread }_{\mathrm{it}}+\beta_{6} \mathrm{GDP}_{\mathrm{it}}+\beta_{7} \text { Exrate }_{\mathrm{it}}+\varepsilon_{\mathrm{it}}
\end{aligned}
$$

Regression methods include Pooled OLS model, fixed effect model (FEM) and random effect model (REM). After selecting the appropriate regression method that is suitable for the model, the research team conducted testing and selecting models as well as assessing the defects of the selected model. In the events of defects that violate the hypothesis, the research team will proceed with the generalized least square (GLS).

In addition, there is a mutual relation among independent variables; therefore, the next goal of the study will be considering the effect of other independent variables on profitability, then the impact of profitability on the corporate

\begin{tabular}{|c|c|c|c|c|c|}
\hline No & Variable & Type & Code & Method of calculation & Expected sign \\
\hline 1 & Distance to default & Dependent & DD & Specified in section 3.2 & \\
\hline 2 & Profitability & Independent & ROE & Profit after tax /Equity & $(+)$ \\
\hline 4 & Financial leverage & Independent & DOE & Liabilities/Equity & $(-)$ \\
\hline 5 & Scale & Independent & SIZE & In(Total asset) & $(+)$ \\
\hline 6 & Spread & Independent & SPREAD & $\begin{array}{l}\text { Interest rate fluctuation for the period of } \\
\text { one year or } 5 \text { years. }\end{array}$ & $(+)$ \\
\hline 8 & Exchange Rate & Independent & Exrate & & $(+)$ \\
\hline
\end{tabular}
value. Thus, the research model was built in a form of the path structure model as follows (Figure 1):

Table 1: Calculation and expected signs of variables

Source: Summary by authors 


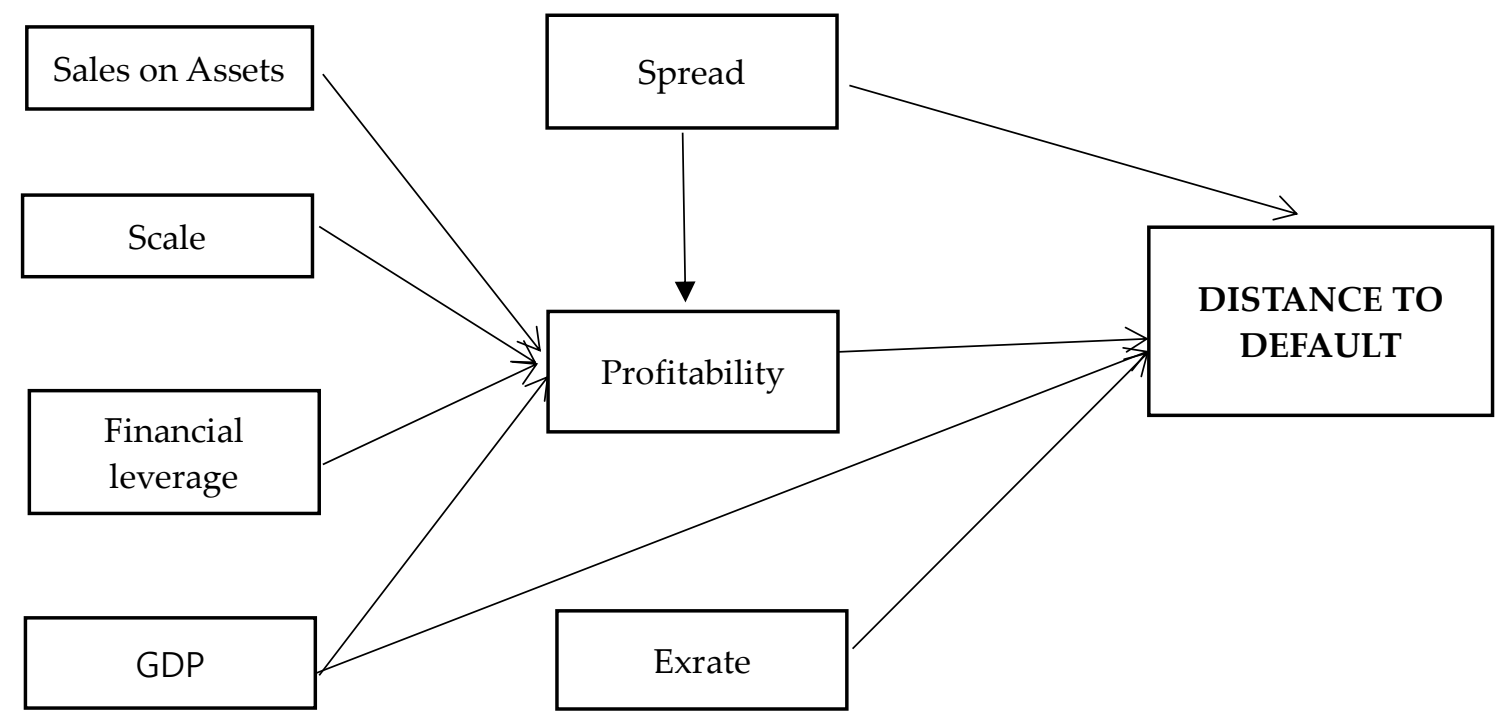

Figure 1: A path structure model

\section{Research Results}

Authors should discuss the results and how they can be interpreted in perspective of previous studies and of the working hypotheses. The findings and their implications should be discussed in the broadest context possible. Future research directions may also be highlighted. The descriptive statistics showed that the lowest DD value in the model is 0 and the standard deviation is 1.74 . Meanwhile, the highest average value belonged to the variable ROE with $3.55 \%$.

Table 2: Descriptive statistics of variables

\begin{tabular}{|l|l|l|l|l|}
\hline \multicolumn{1}{|c|}{ Variable } & \multicolumn{1}{c|}{ Mean } & \multicolumn{1}{c|}{ Standard deviation } & \multicolumn{1}{c|}{ Min } & \multicolumn{1}{c|}{ Max } \\
\hline DD & 2.22986 & 1.747406 & 0 & 123 \\
\hline ROE & 3.557426 & 3.195171 & -0.56 & 6.23 \\
\hline ROA & 1.830288 & 1.855675 & -0.24 & 16.294 \\
\hline SIZE & 14.04135 & 1.126073 & 12.277 & 0.792 \\
\hline SOA & 0.254011 & 0.213583 & 0.016 & 4.277 \\
\hline DOE & 1.348301 & 1.113977 & 0.149 & 3.75 \\
\hline SPREAD & 1.77471 & 0.978213 & -0.123 & 0.079 \\
\hline GDP & 0.060161 & 0.008789 & 0.047 & 0.034 \\
\hline EXRATE & 0.006421 & 0.010148 & -0.003 & \\
\hline
\end{tabular}

Source: Calculations by authors

Table 3 showed the correlation coefficient among variables. The purpose of examining the close correlation between independent and dependent variables is to eliminate factors which can lead to multicollinearity before running regression models. The correlation coefficient among the independent variables in the model has no pair greater than 0.8 , so it is unlikely for the multicollinearity phenomenon to occur. When adopting the regression model, the authors group used the coefficient VIF to check up.

Table 3 : Correlation Matrix

\begin{tabular}{|c|c|c|c|c|c|c|c|c|c|}
\hline & DD & ROE & ROA & SIZE & SOA & DOE & SPREAD & GDP & EXRATE \\
\hline DD & 1 & & & & & & & & \\
\hline ROE & 0.2722 & 1 & & & & & & & \\
\hline ROA & 0.5036 & 0.8809 & 1 & & & & & & \\
\hline SIZE & -0.0469 & 0.0242 & -0.0854 & 1 & & & & & \\
\hline SOA & -0.0409 & 0.2526 & 0.1822 & -0.2509 & 1 & & & & \\
\hline DOE & -0.5848 & -0.0485 & -0.3713 & 0.2764 & 0.0869 & 1 & & & \\
\hline SPREAD & 0.0189 & -0.0511 & -0.0515 & 0.07 & -0.0315 & 0.0143 & 1 & & \\
\hline GDP & 0.1421 & 0.1159 & 0.1009 & 0.042 & 0.0375 & -0.0108 & 0.0734 & 1 & \\
\hline EXRATE & 0.0631 & 0.0816 & 0.0748 & -0.0296 & 0.0349 & -0.0141 & -0.3115 & 0.2679 & 1 \\
\hline
\end{tabular}

Source: Calculations by authors 
For independent variable of ROE (Table 4), the authors compared and chose which model would be the appropriate one: OLS, FEM or REM. To examine and select the appropriate model among the three regression methods above, the authors used F-test and Hausman test. Via F test we noticed Prob $>\mathrm{F}=0.000<\alpha=5 \%$, therefore, with a statistically significant level of $5 \%, \mathrm{H}_{0}$ was rejected. That meant, with the data collected, it was shown that the method that run the FEM model was appropriate and that OLS was not suitable due to the existence of fixed effects in each business over time. After selecting the FEM model instead of OLS running method, the authors studied in turn estimates of the existing table data based on the method of running FEM and REM models. Based on the results of running the FEM and REM models, the authors verified Hausman to compare and select FEM or REM models. The Hausman test results are presented in Table 4. It can be seen that, Prob $>$ chi $2=0.000$ i.e, P_value $=0.000<\alpha=5 \%$, therefore, it is sufficiently grounded to reject the hypothesis $\mathrm{H}_{0}$, then fixed effects (FEM) are more appropriate than random effects (REM). Through tests, the method of running FEM model proved to be the best selected.

Table 4: Multi-variable regression results, independent variable of ROE

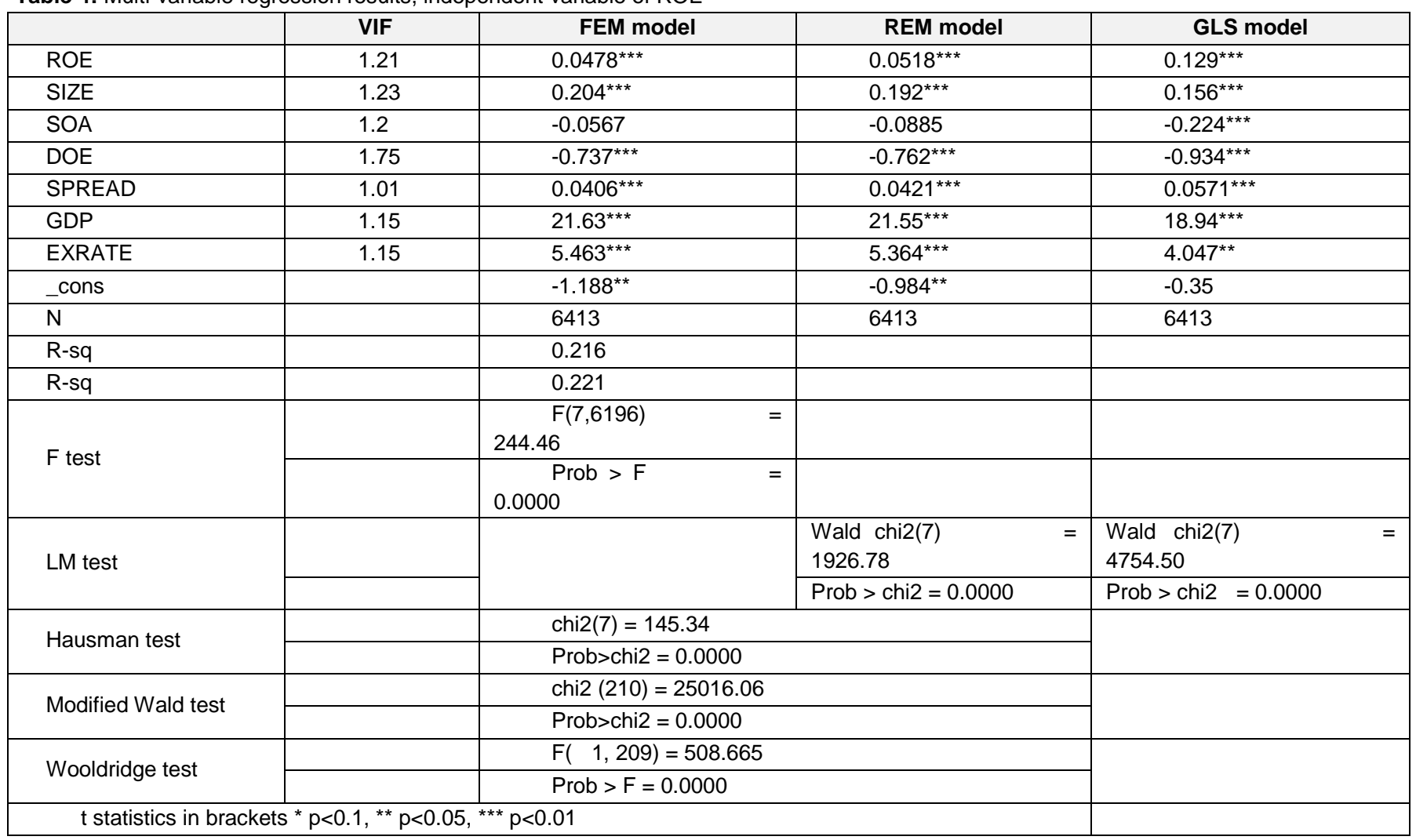

Source: Calculations by authors

However, before analyzing the influencing factors on DD in details, the author used the following tests: heteroscedasticity, multicollinearity, autocorrelation and made necessary amendments to overcome restrictions of the model.

Checking the multicollinearity: To detect the multicollinearity in the model, the author used VIF Variance Inflation Factor. There were various suggestions for the value of VIF, but the most common was 2, whereby the maximum level of VIF that exceeded that value could lead to the multicollinearity. The results of VIF coefficient of variables were all less than 2, proving that multicollinearity didn't exist.

Checking the autocorrelation: The Wooldridge test method was used to test whether there was autocorrelation for regression models. Assume the hypothesis: H0: no autocorrelation phenomenon; H1: autocorrelation exists. If the test results show $\mathrm{P}$ _value $=0.0000<\alpha=0.05, \mathrm{H} 0$ hypothesis will be rejected, i.e. there is autocorrelation.

Checking the heteroscedasticity: To test whether the heteroscedasticity existed in the model, the authors used Modified Wald test. With the hypothesis H0: there is no heteroscedasticity, H1: heteroscedasticity does exist. The test result showed that P-value was small (less than 0.05 default), hypothesis H0 was rejected and hypothesis $\mathrm{H} 1$ is accepted. Based on the results shown in Table 4, the coefficient $\mathrm{P}_{-}$value $<\alpha=0.05$. Therefore hypothesis $\mathrm{H}_{0}$ was rejected. The results of model testing showed that the obtained P-value are all equal to $0.000<\alpha(5 \%)$, which implied that hypothesis $\mathrm{H}_{0}$ in which there is no heteroscedasticity was rejected with significance level of $5 \%$. 
Therefore, the author proceeded to overcome defects of regression model by GLS regression method.

Regression results by GLS: After performing regression and testing and selecting the appropriate model of FEM, the authors proceeded to overcome the detected defects of the model via GLS method (Generalized Least Squares). The results presented in Table 4 were those having overcome the defects of the model. Thus, the research results revealed that all seven factors had an impact on and were statistically significant to the distance to default of enterprises. The same method was applied given the change of the measure of profitability. ROA was chosen instead of ROE in the model with the above verification steps. The results are shown in the following table:

Table 5: Multi-variable regression results, independent variable of ROA

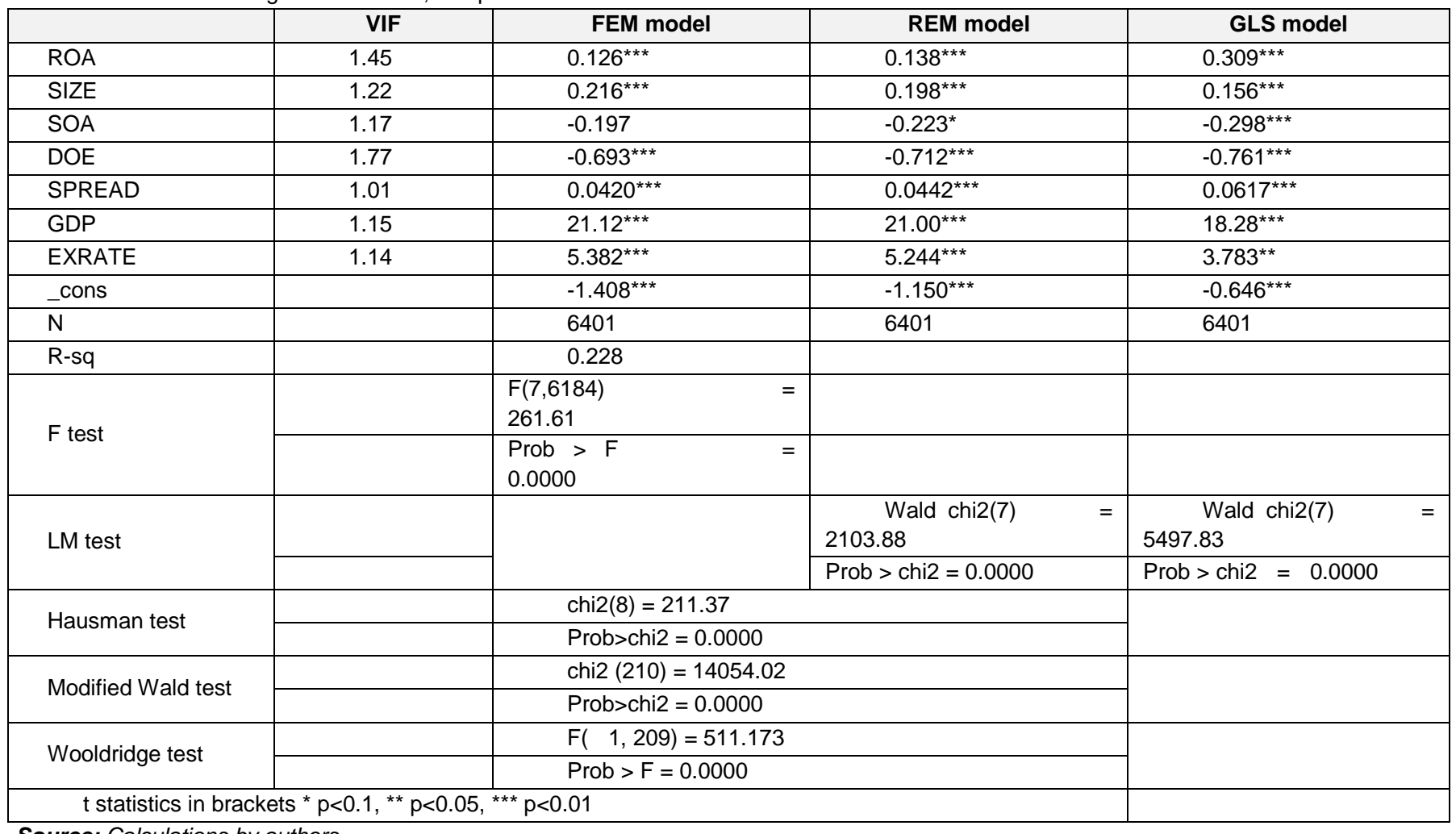

Source: Calculations by authors

The Hausman test results showed that, $P_{-}$value $=0.0000$ $<\alpha=5 \%$; therefore, there is sufficient basis for choosing the fixed effects (FEM). Through testing, methods that run FEM model proved to be the best selected. Using tests to see if the heteroscedasticity existed in the model or not, the autocorrelation showed that the P-value values obtained were all equal to $0.000<\alpha(5 \%)$. This implied the hypothesis $\mathrm{H}_{0}$ didn't exist the heteroscedasticity, which was rejected with significance level of 5\%. Therefore, the author proceeded to overcome defects of regression model through the GLS regression method. Research results (Table 5) showed that the change in profitability would not change the impact of influencing factors on the distance to default. In the path structure model, with Return on Equity (ROE) being the intermediate variable, the variables in the research model all have an impact on the distance to default. 
Table 6: Multi-variable regression results in structure with $\mathrm{ROE}$

\begin{tabular}{|c|c|c|c|c|c|}
\hline \multicolumn{2}{|c|}{ Structural } & Coef. & Std. Err. & $\mathbf{Z}$ & P-value \\
\hline ROE $<-$ & GDP & 33.85162 & 4.526642 & 7.48 & 0.000 \\
\hline ROE $<-$ & SPREAD & -0.1479991 & 0.0412894 & -3.58 & 0.000 \\
\hline $\mathrm{ROE}<-$ & SOA & 4.298916 & 0.1855897 & 23.16 & 0.000 \\
\hline $\mathrm{ROE}<-$ & SIZE & 0.3566235 & 0.0366399 & 9.73 & 0.000 \\
\hline & _cons & -3.964945 & 0.5649694 & -7.02 & 0.000 \\
\hline DD <- & EXRATE & 4.179461 & 2.265197 & 1.85 & 0.065 \\
\hline DD <- & SPREAD & 0.0573952 & 0.0226745 & 2.53 & 0.011 \\
\hline & cons & 0.385792 & 0.1471719 & 2.62 & 0.009 \\
\hline
\end{tabular}

Source: Calculations by authors

In which the scale, revenue on total assets, exchange rates and GDP were directly proportional to profitability of enterprises while capital structure and interest rate fluctuations were inversely proportional to profitability of the enterprise. The result of the sign was similarly illustrated to the profitability variable of ROA. However, with the intermediate variable ROA, the exchange rate had no impact on the distance to default of the business.

Table 7: Multi-variable regression results in structure with ROA

\begin{tabular}{|c|c|c|c|c|c|}
\hline \multicolumn{2}{|c|}{ Structural } & Coef. & Std. Err. & $\mathbf{Z}$ & P-value \\
\hline$R O A<-$ & GDP & 16.61406 & 2.479143 & 6.7 & 0.000 \\
\hline $\mathrm{ROA}<-$ & EXRATE & 5.373744 & 2.257037 & 2.38 & 0.017 \\
\hline ROA $<-$ & SPREAD & -0.077663 & 0.0226314 & -3.43 & 0.001 \\
\hline $\mathrm{ROA}<-$ & $\mathrm{DOE}$ & -0.6905471 & 0.0196424 & -35.16 & 0.000 \\
\hline $\mathrm{ROA}<-$ & SOA & 2.039412 & 0.1016436 & 20.06 & 0.000 \\
\hline$R O A<-$ & SIZE & 0.146069 & 0.0200731 & 7.28 & 0.000 \\
\hline & _cons & -0.7008913 & 0.3094641 & -2.26 & 0.024 \\
\hline$\overline{D D}<-$ & $\mathrm{ROA}$ & 0.4661313 & 0.0101507 & 45.92 & 0.000 \\
\hline $\mathrm{DD}<-$ & GDP & 16.63512 & 2.240842 & 7.42 & 0.000 \\
\hline DD <- & EXRATE & 2.899858 & 2.036901 & 1.42 & 0.155 \\
\hline $\mathrm{DD}<-$ & SPREAD & 0.0774021 & 0.0204063 & 3.79 & 0.000 \\
\hline & _cons & 0.2335017 & 0.1323235 & 1.76 & 0.078 \\
\hline
\end{tabular}

Source: Calculations by authors

\section{Discussion}

The distance to default is influenced by many factors, including those from the macro market and internal factors of the business itself. The test results showed that microfinancial factors had an impact on the distance to default of the enterprise. The above test results also revealed that the financial structure has the inverse effect on the distance to default at the significance level of 5\%. At this level, when the debt scale increases in total capital, together with comparisons with the size of equity, there is an increase in financial risks and in financial dependence as well as debt repayment pressure going up. The risk of inability to repay due debt also increases. This is one of the important factors that shortens the distance to default of enterprises. Thus, the risk of insolvency increases.

Contrary to the financial structure, the profitability of owner's equity was directly proportional to the distance to default of enterprises. This result showed that, although profitability did not directly reflect the cash flow generated, a good profitable enterprise would be an important factor to help facilitate and generate cash flow and at the same time debt was guarenteed when it was due. Therefore, the distance to default increased. This result is consistent with those of previous studies on the distance to default of Chinese listed stock companies (Liang, 2012). The positive relationship between profitability and the distance to default was also clearly reflected in the financial goals of businesses in which the profitability was accompanied by the capacity of debt repayment. In addition, the research results showed that both profitabilitiy measurements (ROA and ROE) had a positive impact on the distance to default. Thus, it can be seen that when the profitability of enterprises increases, the capacity of due debt repayment of enterprises will be ensured. Although the researches on micro factors affecting the distance to default of enterprises are rarely mentioned and tested in previous studies, in the Vietnam's market, the group of indicators which reflects profitability clearly had a positive impact on businesses' capacity of repayment. This is entirely consistent with the goal of maximizing the asset 
value of the business owner. Accordingly, enterprises are required to ensure the profitability and payment targets.

The research results also showed that the sales on assets (SOA) had the inverse effect on the distance to default of enterprises. In theory, high SOA often revealed that enterprises have the ability in management, using and investing their assets well, thereby generating more revenue. However, in practice, this depends much on the asset structure and business performance of the enterprise. Hot growth, illustrated through the fact of SOA being too high, especially if the growth is not sustainable, not stemming from the potential capacity of the business, can lead to many consequences related to the liquidity or resilience to volatility, which results in an increase in likelihood of default.

In addition to the micro-financial factors, the size of enterprises is also an important factor affecting the likelihood of default of an enterprise. Although this impact was not as clear as that of profitability or capital structure, the results still showed an effect of firm size on the distance to default of enterprises. This result is suitable for Vietnamese conditions when insolvency occurs to all businesses of different sizes. However, small enterprises will encounter many difficulties in overcoming the economic recession and the risk of insolvency increases.

The results also revealed that a group of macro factors had an influence on the distance to default of businesses, including spread, GDP and trade balance (via exchange rates). Gross domestic income had certain impacts on the distance to default of businesses. This was also a basic indicator measuring the national economic cycle. When the recession economy was cyclical, it was more demanding for enterprises to access credit (Figlewski, Frydman, \& Liang, 2012). Therefore, businesses would have more difficulties in mobilizing capital for business operations. Hardship in access to capital caused pressure to pay for businesses (Laurin \& Martynenko, 2009; Qu, 2008). In addition to mobilizing debts by credits from financial institutions, bond mobilization was one of the important sources of funding to supplement the long-term capital of enterprises. The fluctuation of interest rates had an impact on the distance to default of the business for Vietnamese enterprises. This result is consistent with that of a study conducted by Laurin and Martynenko (2009).

\section{References}

Pranowo, K., Achsani, N. A., Manurung, A. H., \& Nuryartono, N. (2010). Determinant of corporate financial distress in an emerging market economy: Empirical evidence from the Indonesian stock exchange 2004-2008. International Research Journal of Finance and Economics, 52(1), 81-90. Retrieved from http://achsani.blog.mb.ipb.ac.id/files/2010/11/irjfe_52_0 8.pdf
Altman, E. I. (1968). Financial ratios, discriminant analysis and the prediction of corporate bankruptcy. The Journal of Finance, 23(4), 589-609. DOI: 10.2307/2978933

Arora, N., Bohn, J. R., \& Zhu, F. (2005). Reduced form vs. structural models of credit risk: A case study of three models. Journal of Investment Management, 3(4), 1-43. DOI:10.1002/9781119201892.ch7

Bharath, S. T., \& Shumway, T. (2004, December). Forecasting default with the KMV-Merton model. AFA 2006 Boston Meetings Paper. http://dx.doi.org/10.2139/ssrn.637342

Blundell-Wignall, A., \& Roulet, C. (2013). Business models of banks, leverage and the distance-to-default. $O E C D$ Journal: Financial Market Trends, 2012(2), 7-34. https://doi.org/10.1787/fmt-2012-5k4bxlxbd646

Crouhy, M., Mark, R., \& Galai, D. (2001). Risk management. New York, NY: McGraw Hill.

Figlewski, S., Frydman, H., \& Liang, W. (2012). Modeling the effect of macroeconomic factors on corporate default and credit rating transitions. International Review of Economics \& Finance, 21(1), 87-105. https://doi.org/10.1016/j.iref.2011.05.004

Jessen, C., \& Lando, D. (2015). Robustness of distance-todefault. Journal of Banking \& Finance, 50, 493-505. https://doi.org/10.1016/j.jbankfin.2014.05.016

Lam, C. D., \& Phan, D. A. (2009). Application of KMVMerton model to the quantification of the relations between the asset guarantee, the borrower's funds apportionment and the credit risk. Journal of Science and Technology - University of Danang, 2(31), 1-6.

Laurin, M., \& Martynenko, O. (2009). The influence of macroeconomic factors on the probability of default (Master Thesis). Lund University, Lund, Sweden. Retrieved from http://lup.lub.lu.se/luur/download?func=downloadFile \&r ecordOId=1486524\&fileOId=1647104

Le, D. C., \& Le, T. A. (2012). Combining CvaR model and Merton-KMV model to measure default risk: Empirical evidence in Vietnam. Journal of Development and Integration, 5(15), 10-15. Retrieved from http://www.vjol.info/index.php/kttc/article/view/12182/1 1143

Le, L. H. (2010). Application of Option Pricing Theory on forecasting firm default risk: KMV model. Asian Journal of Economics and Banking, 49, 37-41. Retrieved from http://www.vjol.info/index.php/NH/article/view/14420/1 2947

Leland, H. (2002). Predictions of expected default frequencies in structural models of debt. Paper presented at the GRETA conference: Assessing the Risk of Corporate Default, Venice, Italy.

Liang, X. (2012). An empirical estimation of the default risk of Chinese listed company based on the Merton-KMV Model (Master's Thesis). Bergen, Norway: Norwegian School of Economics. Retrieved from https://pdfs.semanticscholar.org/b6bc/7aead6bca4f530cc e44f6f5c02378982be54.pdf 
Merton, R. C. (1974). On the pricing of corporate debt: The risk structure of interest rates. The Journal of Finance, 29(2), 449-470.

Pesaran, M., \& Schuermann, T. (2003). Credit risk and macroeconomic dynamics. Medium Econometrische Toepassingen, 11(1), 27-32.

Qu, Y. (2008). Macroeconomic factors and probability of default. European Journal of Economics, Finance and Administrative Sciences, 13, 192-215.
Ufo, A. (2015). Impact of financial distress on the leverage of selected manufacturing firms of Ethiopia. Industrial Engineering Letters, 5(10), 6-11.

Yadiati, W. (2017). The influence of profitability on financial distress: A research on agricultural companies listed in Indonesia Stock Exchange. International Journal of Scientific \& Technology Research Volume, 6(11), 233-237. 